\title{
THE DIGESTIBILITY AND UTILIZATION OF EGG PROTEINS
}

\section{THE USE OF RAW EGGS IN PRACTICAL DIETETICS}

\author{
$\boldsymbol{B} \boldsymbol{g}$ \\ W. G. BATEMAN
}

From the Thesis Submitted for the Degree of Doctor of Philosophy Yale University, 1916 



\title{
THE DIGESTIBILITY AND UTILIZATION OF EGG PROTEINS.
}

\author{
BY W. G. BATEMAN. \\ (From the Sheffield Laboratory of Physiological Chemistry in Yale \\ University, New Haven.)
}

(Received for publication, June 24, 1916.)

In 1898 Steinitz noted that the ingestion of raw egg-white by dogs was followed by vomiting and diarrhea. This interesting observation appears to have passed almost unnoticed, although no other native proteins are known to give rise to such digestive disorders. When these same facts were observed by Mendel and Lewis in 1913, their possible bearing on the wide spread use of raw eggs in various diets, especially by the sick, prompted the following study.

The Behavior of Egg-White in the Alimentary Tract.

Experiments with Dogs.

Native Egg-White.-Uncooked egg-white fed in any large quantity to dogs invariably caused diarrhea of more or less severity. The feces were soft, pasty, or liquid depending upon the amount of material ingested and upon the individual susceptibility of the subject. The more liquid stools were light in color, and of very offensive odor. Many of them contained much mucus, and residues of unchanged egg-white and of other foodstuffs. Upon stanting the surface dried rapidly so as to assume a glazed or varnished appearance. Water extracts of the feces, when boiled, yielded varying amounts of coagulated protein material. The coagulation temperature varied from $68-73^{\circ}$. When an equal volume of saturated ammonium sulfate solution was added to the extract, the latter became turbid, but the grayish precipitate contained only a trace of protein. The addition of acid or of more saturated ammonium sulfate solution to the filtrate caused 
the formation of heavy precipitates which acted like ovalbumin. The substance, however, could not be obtained in crystals. The protein in the feces, then, appeared to be unchanged egg-white. The stools of firmer 'consistency contained less coagulable material than those which were liquid or semi-liquid. Even the apparently formed stools sometimes yielded small amounts of protein upon extraction. In this connection Tsuchiya's (1909) statement that albumin is never found in real formed feces but is usually associated with diarrhea is pertinent.

After eating meals containing enough raw egg-white to induce diarrhea, the subjects usually lost weight to the extent of from 0.25 to 0.6 kilo, or from 3 to 8 per cent of the body weight. Some of the dogs remained stationary in weight, but none showed an increase in this respect.

Vomiting only rarely occurred in consequence of ingesting native egg-white and then only after the larger amounts. The ejected material was practically unchanged by its stay in the stomach.

In a few cases small intestinal hemorrhages were noticed, pointing to irritation of the intestinal mucosa. This occurred only after several days' feeding of the raw food or after much straining at stool.

These abnormal conditions ceased promptly upon substituting meat or "dog biscuit" for the egg-white and could be called forth again by the reverse. In no case was there any "hangaver" effect. Indeed the cessation of egg-white meals was usually followed by constipation. The digestive disturbances which result from feeding dogs native egg-white are, therefore, caused directly by this substance.

Urine, obtained by catheterization on those days when the animals had diarrhea, usually gave negative results when tested for albumin; but occasionally small amounts were found present. These samples of urine also contained very little indican, due no doubt to the rapid emptying of the gut.

Amount of Egg Necessary to Produce Diarrheal Symptoms.The effects produced by the egg-white were roughly proportional to the amounts ingested. With dogs of 5.5 to 7 kilos in weight the white of one egg causes no or little effect, two eggs may cause softening of the feces, three cause marked softening, and four or 
five induce more or less severe diarrhea. The last symptom, then, is brought about by the ingestion of 1 to $1.5 \mathrm{gm}$. of native eggwhite per kilo of body weight. This figure is lower for the heavier animals since dogs weighing from 10 to 12 kilos may develop diarrhea by eating the whites of five to seven eggs. There is much variation in the sensitiveness of the subjects, however; for a large dog may be more easily affected than a small one by the same amount of protein.

Other Factors.-Diarrhea followed the ingestion of: (1) native egg-white unmixed with other foodstuffs; (2) native egg-white beaten with milk; (3) raw egg-white thoroughly mixed with cracker-meal and lard; (4) raw egg-white thoroughly mixed with cracker-meal and lard and well flavored with extract of beef. The first two types of meal produced the laxative effect more quickly than the other two, the stools being passed in 8 to 12 and 12 to 20 hours respectively. The presence of a secretagogue such as meat extract in fairly large amount had no effect on the time of appearance or on the severity of the diarrhea. When a meal containing the whites of four or five eggs was divided into three portions which were fed to the dog several hours apart, the abnormal stool was later in appearing than when the meal was eaten all at the same time, and the diarrhea usually not so extensive. Conversely, if three of four egg-whites were fed at each meal sevveral liquid stools were passed each day.

Tolerance.-It was noticed that when the raw protein was fed for several days in succession its ill effects gradually waned. The time necessary for the abatement of the diarrheal action varied from 3 to 5 days. If then the ingestion were continued, there succeeded a period of alternate days of diarrhea and constipation after which time the egg ceased to exert any marked action. The tolerance thus developed lasted for a short time even after the feeding of the uncooked material was discontinued. These facts are brought out in the following typical protocol.

Dog 1 , a healthy terrier bitch weighing 6.52 kilos, received every day a meal containing the whites of four raw eggs well mixed with $60 \mathrm{gm}$. of cracker-meal and $20 \mathrm{gm}$. of lard. On the 1st day this caused severe diarrhea with a fall in weight to 6.31 kilos. On the 2 nd day the diarrhea continued and the animal vomited some of the meal-one of the rare cases when this happened. The weight fell to 5.96 kilos. The stool on the $3 \mathrm{rd}$ 
day consisted of a smaller amount of semi-liquid feces. No further vomiting occurred but the weight fell to 6.9 kilos. On the 4 th day the pasty feces were much smaller in bulk while the weight rose slightly. This improvement was followed on the 5th day by rather bad diarrhea but the weight was not changed and after this time there was no further loss in weight. The feces of the 6th day were small in amount and pasty. On the next 2 days no feces were passed. The 9 th day's stool consisted of a large amount of fairly formed feces. On the 10th day no fecal matter was passed. The quantity of egg given was now increased to five whites but notwithstanding this the next 2 succeeding days showed well formed feces. On the 13th day the stool was small and somewhat pasty while it was well formed again on the next day. At this point the subject was put on a meat diet for 2 days. Then a meal containing the whites of five eggs failed to cause diarrhea. After 2 days more of meat diet, however, the whites of four eggs in the meal brought forth a liquid stool. In one subject this period of induced "immunity" lasted for 12 days.

This tolerance recalls that acquired by the dogs subjected to peritoneal injections of raw egg-white as observed by Cramer (1908). He found that the protein was partly used and partly excreted in the urine. The quantity utilized rose gradually after repeated injections. Hamburger (1902) and Oppenheimer (1904) have observed this as well. That all proteins do not appear in the urine after injection intraperitoneally was shown by Mendel and Rockwood (1905) who found that edestin and excelsin were not excreted by the kidneys after introduction in this way.

Utilization.-The finding of unchanged egg-white in the diarrheal feces showed this foodstuff to be poorly utilized. The extent to which it was used was roughly shown by extracting the 24 hour feces with cold water, boiling this extract, and drying the coagulated material. The feces were made easier to handle by adding bone-ash to the meals and the feces of one period were marked off from those of another with lamp-black. After the ingestion of four to five egg-whites containing 15 to $19 \mathrm{gm}$. of protein, from 30 to 50 per cent of this could be recovered as coagulum. The latter, of course, contained varying amounts of occluded substances. More exact estimates of utilization were furnished by determining the amount of nitrogen in the feces by the Kjeldahl method. This is open to the objection that a portion at least of the fecal nitrogen is not derived from the undigested foods but is contained in unadsorbed material of the intestinal secretion and in epithelial cells from the intestinal tract. 
According to Hammerl, Kermanner, Moeller, and Prausnitz (1897) and Tsuboi (1897) a large part of the nitrogen in the feces comes from these sources. Still another portion may be derived from the organisms living in the alimentary canal, for Osborne and Mendel (1914) have shown that a not inconsiderable part of the feces may consist of bacterial residues. But while the method does not show the exact amount of material digested, the figures so obtained do serve to show the relative degree of utilization. The following protocols are typical.

TABLE I.

Utilization of Raw Egg-White by Dog 1 .

\begin{tabular}{|c|c|c|c|c|}
\hline \multirow{2}{*}{ Day. } & \multirow{2}{*}{ Food. } & \multicolumn{2}{|c|}{ Nitrogen. } & \multirow{2}{*}{ Utilization. } \\
\hline & & In food. & In feces. & \\
\hline & & $g m$. & $g m$. & per cent \\
\hline 1 & Meat............ & 2.50 & 0.13 & 94.7 \\
\hline 2 & “ & 2.50 & 0.12 & 95.2 \\
\hline 3 & “ & 2.50 & 0.13 & 94.8 \\
\hline 4 & Raw egg-white. & 2.42 & 1.22 & 49.8 \\
\hline 5 & " $\quad$ " $\quad$ & 2.42 & 1.07 & 56.0 \\
\hline 6 & Meat. & 2.50 & 0.17 & 93.1 \\
\hline
\end{tabular}

TABLE II.

Utilization of Raw Egg-White by Dog 2 .

\begin{tabular}{|c|c|c|c|c|}
\hline \multirow{2}{*}{ Day. } & \multirow{2}{*}{ Food. } & \multicolumn{2}{|c|}{ Nitrogen. } & \multirow{2}{*}{ Utilization. } \\
\hline & & In food. & In feces. & \\
\hline & & $g m$. & $g m$. & per cent \\
\hline $1-3$ & Meat........ & 9.04 & 0.33 & 96.3 \\
\hline 4 & Raw egg-white..... & 3.16 & 1.20 & 62.0 \\
\hline 5 & 646 & 3.18 & 1.28 & 59.5 \\
\hline
\end{tabular}

TABLE III.

Utilization of Raw Egg-White by Dog 4.

\begin{tabular}{c|c|c|c|c}
\hline \multirow{2}{*}{ Day. } & \multirow{2}{*}{ Food. } & \multicolumn{2}{|c|}{ Nitrogen. } & Utilization. \\
\cline { 3 - 4 } & & In food. & In feces. & \\
\hline & & $g m$. & $g m$. & per cent \\
1 & & & \\
2 & Raw egg-white....... & 3.21 & 1.06 & 69.0 \\
& Meat.............. & 3.05 & 0.13 & 95.8 \\
\hline
\end{tabular}


TABLE IV.

Utilization of Raw Egg-White by Dog 6 .

\begin{tabular}{c|c|c|c|c}
\hline \multirow{2}{*}{ Day. } & \multirow{2}{*}{ Food. } & \multicolumn{2}{|c|}{ Nitrogen. } & \multirow{2}{*}{ Utilization. } \\
\cline { 3 - 4 } & & In food. & In feces. & \\
\hline & & $g m$. & $g m$. & per cent \\
1 & Meat............. & 3.06 & 0.11 & 97.2 \\
2 & Raw egg-white...... & 2.97 & 1.23 & 58.6 \\
\hline
\end{tabular}

Native egg-white, then, was poorly made use of by these dogs, since from 30 to 50 per cent of the amount ingested was wasted by being ejected with the feces. When Mendel and Lewis (1913) fed this material to dogs only about half of the nitrogen in the meals appeared in the urine for the following 24 hours as contrasted with almost all when meat, cascin, edestin, and other proteins replaced the egg-white. Steinitz (1898) reported unchanged egg-white in the feces in considerable quantity but does not state the figures. Vogt (1906) and Falta (1906) found that the nitrogen in uncooked egg-white superimposed upon a standard diet was excreted much more slowly in the urine than that ingested in the form of other proteins. The former ascribes this to a slower rate of digestion and the latter to the longer time necessary to catabolize the larger cleavage products which he supposes adsorbed. Both explanations are fundamentally the same-the native egg-white resists digestive processes.

After the dogs had grown to tolerate the egg-white better, the utilization was better as well. For example, the feces passed by the subject described in the protocol under "tolerance" on the 9th and 12 th days were analyzed for nitrogen with results shown in the following table.

TABLE V.

Improvement of Utilization with Tolerance.

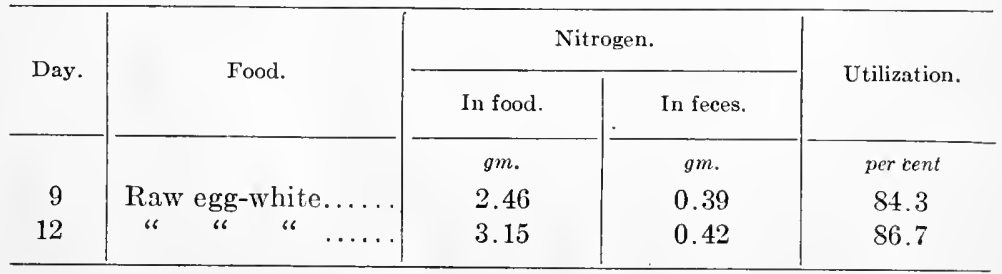


Dried Egg-White.-The material was prepared by drying native egg-white in the air at temperatures below $50^{\circ}$. 15 to $20 \mathrm{gm}$. of the dry powder dissolved in water and fed in the usual meal of cracker-dust and lard were as active in causing diarrhea as the raw egg-white itself. This was also true with the subjects of Mendel and Lewis who consider the dried egg-white dissolved in water as equivalent to the original material. Neither was the utilization of the egg-white improved by drying. Several samples were kept at a temperature of about $40^{\circ}$ for periods varying from 3 to 7 days, but this again made little difference in their digestibility. Falta (1906) made experiments using desiccated material and found in three cases a utilization of 80 per cent, 80 per cent, and 61 per cent respectively, while the same dogs used almost 100 per cent of casein and gelatin. The method used by Falta was that of superimposition. The feces were usually not analyzed but one dog was noted as having diarrea. LeClerc and Cook (1906), in the course of work on another topic, fed to a dog meals containing dried albumin, cracker-dust, and lard together with sodium phosphate. They give the following figures:

TABLE V1.

Nitrogen Balance on Diet Containing Egg-White (LeClerc and Cook).

\begin{tabular}{c|c|c|c|c|c}
\hline \multirow{2}{*}{ Experiment. } & \multicolumn{4}{|c|}{ Nitrogen. } & \multirow{2}{*}{ Utilization. } \\
\cline { 2 - 4 } & In food. & In urine. & In feces. & Balance. & \\
\hline & $g m$. & $g m$. & $g m$. & $g m$. & per cent \\
\cline { 3 - 4 } 1 & 16.72 & 9.55 & 9.90 & -1.73 & 40.8 \\
2 & 16.71 & 10.89 & 6.18 & -0.37 & 63.0 \\
3 & 17.52 & 6.62 & 13.85 & -3.05 & 21.0 \\
\hline
\end{tabular}

For the first and third experiments practically all the nitrogen was supplied in the form of egg-white, while for the second, half was in this form and half in egg-yolk. The differences in the balance and utilization are striking. On the last day it will be noted that the nitrogen in the feces was over twice that in the urine. These results may be compared with those given later in this paper.

To determine what effect standing might have on the dried egg-white, experiments were made with commercial albumin 
which had been in the laboratory for some years. This caused diarrhea although not so severe as that induced by either the native or freshly dried protein. Its activity was not further diminished by being exposed to bright light for 2 months. The dogs showed considerable ability to overcome the effects of this substance. The following describes a typical case.

Dog 4 was a healthy terrier bitch weighing 6.3 kilos. Its daily meal consisted of $60 \mathrm{gm}$. of cracker-dust, $20 \mathrm{gm}$. of lard, and $15 \mathrm{gm}$. of commercial egg-albumin dissolved in $150 \mathrm{cc}$. of water. On the 1st day severe diarrhea developed and the utilization of the protein was only 76 per cent. Next day the diarrhea was much less extensive but the weight of the subject had fallen to 6 kilos. On the 3 rd day no feces were passed but the quantity on the 4th day was large while the consistency was pasty. The utilization was now 82 per cent. On the 5 th day there was only a small quantity of feces and this was true of the 7 th day as well. On the alternate days - 6th and 8th- the feces were large in quantity and on the last named day better formed. The utilization had risen to 86.5 per cent. The native egg-white and the commercial product act, then, in much the same manner.

In still other experiments the dried egg-white was fed without previous hydration or solution, only enough water being added to the meal to make it eatable. In these cases diarrhea did not generally occur. Water was left in the cages but no more was taken than usual. The quantity of urine was diminished and indican was usually present in notable amounts. The feces were delayed, sometimes not being passed until 23 to 25 hours after the meal. When finally passed they were soft, unformed, of strong odor, and contained much mucus. The utilization was better than in the previous experiments, since it was generally above 80 per cent. In a few cases, however, diarrhea did result from dried egg-white fed in this way.

Cooked Egg-White.-When dogs ate the well cooked whites of four to six eggs they did not display the ill effects attending the use of the same quantities of uncooked egg-white. Moreover, the cooked material was as effective in stopping the diarrhea caused by the raw eggs as was meat. The utilization was very good, being in the neighborhood of 90 per cent, as shown below. The marked difference in the metabolism of the same substance cooked on the one hand and raw on the other is brought out in the following tables. 
TABLE VII.

Nitrogen Balanee of Dog 1.

\begin{tabular}{|c|c|c|c|c|c|c|}
\hline \multirow[b]{2}{*}{$\vec{\Xi}$} & \multirow{2}{*}{ Meal. } & \multicolumn{4}{|c|}{ Nitrogen. } & \multirow{2}{*}{ Utilization } \\
\hline & & In food. & In urine. & In feces. & Balance. & \\
\hline & & $g m$. & $g m$. & $g m$. & $g m$. & per cent \\
\hline 1 & $\begin{array}{l}\text { Cooked egg-white, } \\
\text { cracker, lard..... }\end{array}$ & 3.76 & 3.20 & 0.33 & +0.23 & 91.2 \\
\hline 2 & . " " & 3.76 & 2.91 & 0.39 & +0.46 & 89.6 \\
\hline 3 & $\begin{array}{l}\text { Raw egg-white, } \\
\text { cracker, lard... }\end{array}$ & 3.81 & 3.10 & 1.87 & -1.16 & 51.0 \\
\hline 4 & " & 3.74 & 3.27 & 1.31 & -0.84 & 62.2 \\
\hline 5 & $\begin{array}{l}\text { Cooked egg-white, } \\
\text { cracker, lard...... }\end{array}$ & 3.76 & 3.15 & 0.43 & -0.18 & 88.5 \\
\hline
\end{tabular}

TABLE V1I1.

Nitrogen Balance of Dog 5.

\begin{tabular}{|c|c|c|c|c|c|c|}
\hline \multirow[b]{2}{*}{ ๑ } & \multirow{2}{*}{ Meal. } & \multicolumn{4}{|c|}{ Nitrogen. } & \multirow{2}{*}{ Utilization } \\
\hline & & In food. & In urine. & In feces. & Balance. & \\
\hline & & $g m$. & $g m$. & $g m$. & $g m$. & per cent \\
\hline 1 & $\begin{array}{c}\text { Cooked egg-white, } \\
\text { cracker, lard.... }\end{array}$ & 4.32 & 3.95 & 0.43 & -0.06 & 90.0 \\
\hline 2 & $\begin{array}{l}\text { Raw egg-white, } \\
\text { cracker lard }\end{array}$ & +36 & 3 & & -0.72 & 58.5 \\
\hline 3 & Cooked egg-white. & $\begin{array}{r}+32 \\
+.32\end{array}$ & 4.00 & 0.44 & +0.12 & 89.8 \\
\hline
\end{tabular}

It will be seen that the cooked egg-white was not so well utilized as meat. For this two factors other than the nature of the foodstuff may be responsible. One is, that the dogs were fed generously which led as usual to more waste; and the other is the presence in the meal of bone-ash, for Mendel and Fine (1912) have demonstrated that even small amounts of indigestible substances in the food cause a poorer use of protein. Kolpakcha (1888) found egg-white to be excellently utilized by dogs-95 per cent or better-even when large amounts were ingested. Although not specifically stated so, the material was probably cooked. Steinitz (1898), on the contrary, states that considerable quantities of coagulated egg-white were passed in the feces of dogs. The differences may possibly be due to variations in 
the fineness of division since if dogs are allowed to bolt large pieces of hard-cooked egg-white, fragments of the same can generally be distinguished macroscopically in the feces.

The Temperature Necessary to Improve the Digestibility of EggWhite.-The above results show that simple heating of the native egg-white renders it more digestible and affords the organism a chance to make better use of it. At what temperature is this change effected? To determine this the egg-white was heated in a double-boiler for 30 to 45 minutes with constant stirring. At temperatures below $55^{\circ}$ the substance suffered little impairment of its activity in causing diarrhea. This activity is, however, considerably decreased by heating at $55^{\circ}$ or $60^{\circ}$. After being subjected to a temperature of $65^{\circ}$ for half an hour the digestibility of the egg-white is still further enhanced while at $70^{\circ}$ or above, the foodstuff becomes entirely innocuous. Above $55^{\circ}$, more or less coagulation takes place depending upon the degree of alkalinity of the egg-white, while at $70^{\circ}$ the protein is entirely coagulated but is very soft and jelly-like in texture.

\section{Experiments with Rats.}

The subjects were large, healthy, white rats kept in sanitary cages and supplied plentifully with food and water. The meals consisted largely of separator-milk powder ("Klim") mixed well with varying amounts of egg-white, bread-meal, and lard.

When the diet contained 20 per cent of raw egg-white the feces of the subjects were not different from those of controls fed on a mixed diet although occasionally the presence of small amounts of coagulable protein could be demonstrated. When the proportion of egg-white was increased to 40 per cent half of the animals had softened feces, the scybala being larger and longer than normal. Such stools as these always contained unused protein. All the subjects up to this time gained in weight and maintained excellent condition. Tolerance for the unusual foodstuff was quickly gained since after 7 to 10 days' feeding the feces could not be distinguished in appearance from those of the controls.

Next, a new lot of animals were first fed a diet containing 60 per cent of raw egg-white. This caused diarrhea which in some cases was severe. In the latter contingency the body weight 
decreased while the less susceptible animals, on the contrary, gained somewhat or remained stationary. The food was not relished so that the diminished intake played some part when weight was lost. The ill effeets of the native egg-white were still more marked when the proportion in the food was increased to 70 per cent. Several subjects refused to eat after a few days, moping in the eages and neglecting to clean themselves. The feces now became quite liquid at times and often contained mucus. When the fecal matter dried it appeared as though varnished. In a final experiment the rats were fed a mixture of 80 per cent raw egg-white and 20 per eent milk powder of which they partook rather sparingly. They lost weight rapidly, all were afflieted with diarrhea, and after 10 days it was evident that their health was much impaired. Six of these animals while having diarrhea were killed with ehloroform and the intestines examined. In half the cases everything was normal while the degree of intestinal inflammation perceived in the other three did not appear significant.

The use of eooked instead of raw egg-white was followed by no untoward effects. All the rats gained in weight and remained well and active even when the diet contained a large proportion of the coagulated protein.

Falta and Noeggerath (1905) fed rats a diet in which dry egg-white was the only protein. The animals did not live longer than 94 days in the most favorable eases. The weight steadily declined and death followed when the weight fell to two-thirds or three-fifths of its original value. The rats suffered from conjunetivitis and other eye diseases. Knapp (1908) reports similar results. All his rats experienced diarrhea and conjunetivitis. One soon died, the others following in from 17 to 24 weeks, after losing much weight. Maignon (1912) fed rats exelusively on egg-white, either raw or cooked, which was found entirely inadequate to sustain them. Weight was quiekly lost in spite of the inereased quantities of food ingested. Death oceurred after various periods when the body weight had been much reduced-in some cases as much as 40 per cent. Frank and Schittenhelm (1912) also failed to nourish rats when the only protein furnished was egg-white.

Von Knieriem (1885) fed mice exclusively on dry egg-white. They could not maintain existence and some suceumbed in 3 days. Röhmann (1914) used mice as subjects, feeding them mixed diets some of which eontained egg-white. He concluded from the results of his experiments that this substance sustained life poorly in comparison with other proteins. 
All the untoward effects noted by these investigators cannot be ascribed to the egg-white but more justly to the lack in the diet of important food accessories such as the vitamines. Osborne and Mendel (1911) kept rats growing well on rations containing cooked egg-white as sole protein for 170 days and the ensuing decline was arrested, not by changing the protein but by adding a small amount of butter fat. As regards the eye troubles, rats are prone to suffer from epidemies of conjunctivitis and other diseases if poorly nourished or kept in unsanitary surroundings. Both Falta and Noeggerath and Knapp experienced these troubles with other proteins in the diet than egg-white; but they appeared to be milder and more tractable in the former case.

\section{Experiments with Rabbits.}

The experimental animals were kept in metabolism cages and liberally supplied with mixed food. The raw egg-white was fed by means of a stomach sound.

1. Two rabbits each received the whites of two eggs. One passed a small amount of semi-liquid matter while the feces of the other and of a control which received an equivalent quanity of water were normal.

2. Two rabbits each were fed the whites of three eggs. One had moderate diarrhea while the feces of the other were pasty and inereased in quantity above those passed on the mixed food.

3. Three rabbits each were given the whites of two eggs at 10 o'clock and the whites of two more at 2 o'clock. Two were afflicted with diarrhea of some severity. One of them ate most of the fecal matter in preference to food. The third animal passed a large amount of very pasty feces, the seybala being much larger than normal.

Von Knieriem (1885) fed three rabbits each a meal containing:

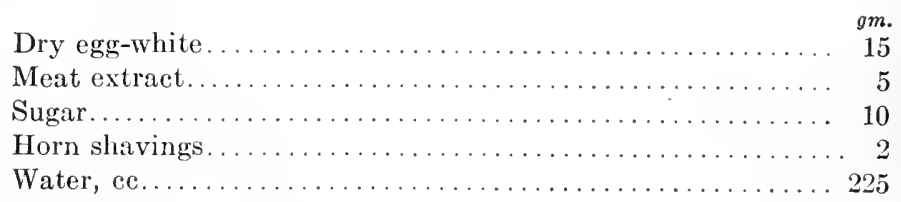

The resulting feces were very soft and abnormal. Utilization of the egg-white in the three cases was calculated to be $61,67.2$, and 70.2 per cent respectively. The character of the feces and the poor utilization of the protein were doubtless due in part to 
the presence in the food of the horn shavings which acted in the same manner as the indigestible substances used in the experiments of Mendel and Fine and Mendel and Lewis. Nevertheless, von Knicriem decided that egg-white was, in contrast to almost all other proteins, poorly digested. Mendel and Rose (1911) found it impossible to feed any large amount of native eggwhite to rabbits without inducing diarrhea.

\section{Experiments on Man.}

Experiments were made with native egg-white and raw eggs upon a number of persons, and the cooperation of still others who were eating raw eggs in order to gain weight was secured. The data collected confirmed the points already brought out. Most of the subjects experienced diarrhea which generally abated after several days' ingestion of the raw foodstuff, and many complained of intestinal discomfort. The material was poorly utilized. These experiments will be discussed more in detail together with the question of the use of raw eggs in practical dieteties, in another place.

The results of these experiments are in accord with those of other investigators. Falta (1906) found raw egg-white to be utilized by man to the extent of 70 per cent. A still lower value, 50 per cent, was reported by Wolf (1912) who has described the peculiar behavior of this foodstuff when ingested by man. He did not observe diarrhea but the feces were of soft consistency. When raw egg-white was in the diet there was over twice as much nitrogen in the feces as when the food contained the same quantity of nitrogen in the form of other proteins. On one occasion the feces contained more nitrogen than did the urine. The latter did not contain albumin, a result in contrast to those of Hamburger (1902) and Cramer (1908) who claimed that albuminuria follower the ingestion of large doses of native egg-white by man. Previously Oertel (1883) had not been able to find albumin in the urine in such cases, and neither did uncooked eggwhite cause an increase in excreted albumin in preexisting albuminuria. Wolf also noted that when either raw or cooked eggwhite was superimposed upon a standard diet there was a delay in the excretion of nitrogen and sulfur, the delay being greater 
in the sulfur elimination. He suggested that the sulfur complexes in the uncoagulated egg-white have considerable power to withstand the action of the digestive enzymes.

Explanations of the Behavior of Egg-White in the Alimentary Tract.

\section{The Effect of Heating on Egg-White.}

The improvement in the digestibility of raw egg-white effected by heating may be brought about by the increased temperature in four different ways. These are: (1) The temperature used in cooking kills any bacteria present; (2) heating changes the physical texture of the egg-white; (3) heating destroys enzymes normally found in this native protein mixture; (4) heating changes the chemical nature of the egg-white.

1. Heating Kills Bacteria.-That bacteria in the egg-white cause the diarrhea attending its use is improbable. It is true that Wiley (1908), Lamson (1909), Pennington (1910), Maurer (1911), and Stiles and Bates (1912) have reported a large percentage of the eggs examined by them infected. But the more recent work of Rettger (1913), who carried out far-reaching tests with the greatest care to prevent accidental contamination, led him to the opposite conclusion. Of the whites of 582 fresh eggs only seven, or 1.2 per cent, showed the presence of bacteria and some of these cases were unquestionably due to contamination. These results are supported by those of Horowitz (1902) and confirmed by Kossowicz (1913). And not only is egg-white usually sterile but it has strong antiseptic properties and in many cases a marked disinfectant action on bacteria as demonstrated by Laschtschenko (1909) and Rettger and Sperry (1912). The bactericidal properties are destroyed by heating the egg-white to $65-70^{\circ}$. In view of these facts it is unlikely that the unusual behavior of native egg-white in the alimentary tract can be due to bacteria.

2. Heating Changes the Physical Texture.-When raw egg-white is heated above $55^{\circ}$ it coagulates and loses its properties as a viscid liquid. It is possible that this change is responsible for the bettered digestibility of the cooked protein especially since, as shown above, this improvement is not brought about by heating at temperatures too low to cause coagulation.

Two sets of dogs were fed meals exactly alike except that one 
received native egg-white and the other cooked egg-white ground to a fine pulp. By the addition of water both types of meal were made as nearly of the same eonsistency as possible. Those meals eontaining the raw foodstuffs always eaused diarrhea while the others did not.

For further evidenee on this point there was added to raw eggwhite enough sodium hydroxide to prevent coagulation when the mixture was heated even above $70^{\circ}$. By this treatment the eggwhite was little altered, only becoming somewhat more viseid; yet when fed to dogs it failed to eause diarrhea.

Other experiments to be cliseussed later in detail also showed that the egg-protein eould be made digestible without changing its fluid eharacter.

While it may be said that the peculiar physical nature of the substance is not per se the factor giving rise to cliarrhea and poor utilization, the protein does, nevertheless, act while in the stomach in an unusual manner. Beaumont (1833) was the first to discover that raw egg-white leaves the stomach more rapidly than other foods, including eooked egg-white itself. Some objeetions may be raised against these early observations beeause of the abnormality of Beaumont's subjeet; but that the protein does act in the manner described has been eonfirmed recently by Cannon (1905), and London and Sulima (1905). The former found the egg-white to pass through the pylorus at a rate eomparable to that of the carbohydrates which are among the first foodstuffs to enter the intestine after ingestion whereas protein leaves the stomach slowly. The egg-white was the only protein to act in this way among those investigated. London and Sulima by means of intestinal fistulas found that the egg-white left the stomach in large gushes, often faster than the peristaltic waves. During its stay in the stomach it retained its alkaline reaction for some time or passed into the intestine in this condition. After feeding a dog native egg-white these workers recovered 73 per cent unchanged from a fistula in the ileum.

The amount of gastric proteolysis undergone by this protein, already deereased by its short stay in stomach, is still further diminished by another unusual property observed by Pawlow (1902); namely, that the egg-white acts ineffectively in stimulating a flow of gastric juice. It aets in this way only like 
so much water. But even this is not the end of the story, for Abderhalden and Pettibone (1912), and Bizarro (1913) state that native egg-white offers considerable resistance to the action of pepsin. If the egg-white is heated, however, and especially if coagulated at $80^{\circ}$, it is more quickly acted upon by the pepsin than when uncooked, and hydrolysis proceeds farther. After the material is once coagulated the rate of digestion is lessened by heating at higher temperatures. The fineness of division of the coagulum also affects the rate of digestion.

We may picture this native protein, then, as quickly leaving the stomach, accompanied by scanty amounts of gastric juice and practically unaltered by pepsin. Perhaps this lack of gastric digestion is at the bottom of the egg-white's unusual behavior as a foodstuff. That it does have a bearing on the subject was shown by feeding dogs partially digested egg-white. The protein together with 0.2 per cent pepsin and 0.2 per cent hydrochloric acid was heated for several hours at $37^{\circ}$. The digestion was continued until the mixture upon neutralization gave a heavy precipitate, in the filtrates from which no coagulable protein could be detected. This material, which was little altered in texture from the original, was as inactive as cooked egg-white in causing diarrhea.

However, Cannon, and London and Sulima have shown that even coagulated egg-white leaves the stomach much more rapidly than other proteins, although less so than when in the native condition. When cooked it does, in contrast to the raw material, call forth an early secretion of hydrochloric acid with which it unites. But the clifference in rate of gastric discharge is not enough to account for the differences in digestibility, so one must consider the behavior of the two in the intestine.

As stated above, the native egg-white in the stomach fails to cause a good flow of gastric juice. According to the mechanism which Bayliss and Starling (1902) propose for the action of secretin, it is probable that once in the intestine the raw egg-white meets comparatively little pancreatic juice since the amount of the latter is proportional to the quantity of acid entering the duodenum-a fact observed by Pawlow (1902) as well. Furthermore, Brüno and Klodnizki (1914) showed that no bile was passed into the intestine when raw egg-white was ingested. 
Okada (1915) has confirmed this to the extent that in his experiments the secretion of bile was small and seemed to be dependent upon the degree of digestion undergone by the protein in the stomach. Coagulated egg-white always caused a good flow of bile.

3. Heating Destroys Enzymes.-In the intestine the digestion of the egg-white is still further checked by the pronounced resistance it exerts against the action of trypsin. Vernon (1904) found the antitryptic activity to be more marked with this protein than with any other. In solutions containing 0.5 to 1.0 per cent of raw egg-white the trypsin action on fibrin was lowered to only 2.7 per cent of the normal, while even one part of eggwhite in 6,000 reduced the activity to 45 per cent of the normal. When the egg albumin was exposed to a temperature of $60^{\circ}$ its antitryptic influence was not diminished and it retained a good deal of its inhibitory power even after coagulation at $100^{\circ}$.

The native egg-white, however, is unlike collagen which is not acted upon at all by trypsin; for Bayliss (1908) has shown that if sufficient time be allowed the enzyme will act as completely upon uncooked as upon cooked egg albumin. For some hours after being brought together the trypsin does not change the eggwhite in the slightest degree and it requires over 70 hours before the digestion equals that of the cooked material under the same conditions. Hedin (1907), Cohnheim (1912), Abderhalden and Pettibone (1912), Long and Johnson (1913), and Bizarro (1913) have all demonstrated the strong antitryptic effect of egg-white which Hammarsten (1912) considers remarkable.

To explain this behavior the existence of a specific anti-enzyme, antitrypsin, has been postulated which is supposed to unite with the trypsin much as an antitoxin does with its corresponding toxin. A later view is that the trypsin is adsorbed by the colloidal egg-white which thus cuts down tryptic activity in much the same way as did charcoal in the experiments conducted by Hedin $(1906, b)$. Recently Maxwell (1915) has shown that boiled starch adsorbs pepsin and so hinders its activity. That eggwhite does act in this manner is suggested by the observations of Delezenne and Pozerski (1903), Vernon (1904), Gompel and Henri (1905), and Hedin (1907) who found that raw egg-white prevents the tryptic digestion of other easily digested proteins. 
It has already been stated that native egg-white resists peptic digestion. It is interesting to note that proteolytic enzymes other than those occurring in the intestinal tract are also unable to act upon this substance. The work of Chittenden, Joslin, and Meara (1892), and Chittenden (1894) showed that raw egg-white was much more poorly digested than coagulated egg-white by bromelin, the proteolytic enzyme of the pineapple. Jonescu (1907) and Sachs (1907) found that papain was practically unable to act upon native egg-white. If the latter was heated or incubated with dilute acids the antiproteolytic action toward papain was destroyed.

If native egg-white contains antitrypsin, then heating may improve its digestibility by destroying the anti-enzyme. Talarico (1910) found that preliminary heating of the egg-white aided tryptic digestion. There was no effect, however, until the temperature reached $70^{\circ}$ after which there was an orderly liberation of amino-acids up to $130^{\circ}$. Frank (1911) also found cooked eggwhite to be better digested than raw, the optimum temperature being $70-75^{\circ}$. At temperatures above this the digestibility decreased in proportion to the hardness of the coagulated material. Bizarro (1913) considered the best temperature to be $80^{\circ}$. In addition to these observers Abderhalden and Pettibone (1912) and Long and Johnson (1913) found the coagulated egg-white much better digested than the raw. The latter observers state that cooked egg-white, however, is acted upon slowly by trypsin as compared to pepsin.

It is significant that the temperature $\left(70^{\circ}\right)$ which was found sufficient to rob the egg-white entirely of its activity in causing diarrhea is the same as that given above for the optimum activity of trypsin.

Beyond the resistance to trypsin the properties of the alleged antitrypsin in the egg-white are little known except that Vernon (1904) found its action much weakened by heating with dilute sodium carbonate. Hedin (1904) also used sodium carbonate to destroy the anti-enzyme.

The following experiments were made to determine whether the antitrypsin could be the source of the unusual behavior of egg-white.

The whites of five to six eggs were dialyzed for several days. 
When fed to dogs this material was effective in causing diarrhea. The antitrypsin, if present, is not diffusible. Cathcart (1904) found that the antitryptic action of blood scrum is not removed by dialysis.

Egg-white was incubated with 0.2 per cent sodium or potassium hydroxide or 0.25 per cent sodium or potassium carbonate for several hours at $37^{\circ}$. Fed to dogs the material was no different in behavior than cooked egg-white. This treatment does not alter the texture to any extent.

The native protein was heated in an incubator at $37^{\circ}$ for 4 to 8 hours with 0.2 per cent acetic or hydrochloric acid. By this treatment it was rendered digestible and no diarrhea followed its use. This process also left the original texture unaltered.

Jobling and Petersen (1915) succeeded in extracting antitrypsin from blood serum with chloroform. It was found impracticable to extract native egg-white with chloroform or ether since a considerable quantity of the protein was precipitated and the liquids, especially the chloroform, did not separate well. After standing for 12 to 24 hours the mixtures were dried rapidly in a current of warm air at room temperature. The dry material was thoroughly mixed with water and fed to dogs. It did not cause diarrhea. Nothing had been removed from the native eggwhite and judging by the work of Jobling and Petersen the treatment was scarcely drastic enough to destroy the anti-enzyme.

Further attempts at extraction were made more successfully by previously drying and powdering the egg-white. In order to make the extraction as complete as possible the mixture of dry egg-white and ether or chloroform was allowed to stand for 4 days, on each of which it was well shaken for a period of 30 to 60 minutes. The extract was then separated and evaporated to dryness at room temperature. The residue from the extract was triturated with water and mixed as well as possible with finely minced, coagulated egg-white. This mixture, assumed to contain any antitrypsin originally in the egg-white, failed to cause diarrhea when fed to dogs. The residues insoluble in chloroform or ether were dried, mixed with water, and fed to dogs with negative results.

It is well known that enzymes in general are soluble in dilute and precipitated by strong alcohol. Egg-white was coagulated with strong alcohol and filtered. If antitrypsin was precipitated by 
the reagent it should be contained in the coagulated protein; yet when this was freed from alcohol and fed to dogs it caused no diarrhea. Neither did the filtrate appear to contain antitrypsin, for the residue obtained from it by evaporation well mixed with cooked egg-white was fed to dogs with no untoward results. In still other experiments the egg-white was precipitated as before with strong alcohol. After filtering, the coagulated protein was finely minced, ground up with dilute alcohol, and finally washed with dilute alcohol. By this treatment it might be supposed that antitrypsin, if present in the egg-white, would first be precipitated and then washed out of the finely divided coagulum by the dilute alcohol. Accordingly the filtrates and washings were evaporated until the alcohol was removed and fed to dogs after being thoroughly incorporated with cooked egg-white. In no case was diarrhea induced. Finally the washed coagulum was fed but proved as ineffective as the extracts.

Those of the above experiments, therefore, which were planned to remove an active substance from egg-white-by extraction or washing-appeared to fail since the separated material did not render cooked egg-white incligestible. In contrast, those experiments calculated to make the native egg-white digestible by destroying the anti-enzyme were successful. It may justly be argued, however, that antitrypsin, even if contained in the residues from the extracts, cannot be mixed intimately enough with cooked egg-white to make it really indigestible.

4. Heating Changes the Chemical Nature.-When egg-white is coagulated its chemical nature is altered. This change may be the causal factor in bettering its behavior in the intestinal canal. Changes of like nature brought about by other agents than heat were similarly effective.

Some of the experiments already described bring out this point. Thus egg-white precipitated with alcohol did not affect dogs as did the original protein. It made no difference whether the precipitate was filtered off at once or allowed to stand in contact with the alcohol for several days. In other experiments the egg-white was denatured by the minimum quantity of moderately strong alcohol and the whole mixture dried quickly at a low temperature. This material sometimes considerably softened the feces of dogs by which it was ingested but this may be due to the fact that the treatment usually leaves some of the original protein unaltered. 
It has already been stated that dried egg-white extracted with chloroform or ether was readily digested. When these residues, from which little had been removed by extraction, were mixed with water and fed to dogs they did not cause diarrhea. Sometimes, after the extraction had been made with ether, the feces were softer than normal. This lack of activity was not because the reagents extracted any active material as shown above, but apparently because the protein was more or less denatured by them. Before extraction the dried egg-white was entirely soluble in water, but the treatment so changed it that much of it became insoluble.

Egg-white was chemically modified in still another way by converting it into alkali-metaprotein. This was prepared by the gradual addition of potassium hydroxide to native egg-white with constant stirring. The transparent jelly was finely divided and thoroughly washed with cold water. Fed to dogs it proved an excellent foodstuff. The feces formed by it closely resembled the normal feces in being dry and crumbly. Klug (1897) found that pepsin from the stomach of dogs digested alkali-albumin better than any other protein in his list, at the bottom of which he placed coagulated egg-white. In general the same thing was true with pig and ox pepsin. Vernon (1904) considered alkalialbumin prepared from egg-white more easily digested by trypsin than the native protein.

As stated previously, if egg-white is partially predigested by pepsin or incubated with dilute acids and bases it loses its ability to cause diarrhea. All of these procedures, in addition to any effect they may have on antitrypsin, change the chemical nature of the egg-white. It is true that some of these changes are not pronounced, but in this respect the altered substances may be like the racemized proteins of Dakin and Dudley (1913) who found that such a slight chemical change as a partial reversal of the direction of polarization was sufficient to convert casein into an entirely indigestible substance.

Résumé.-From the evidence at hand it is reasonable to assume that the indigestibility of the egg-white is due primarily neither to its physical texture nor to any bacteria present. But it seems impossible to make a decision between the other two explanations offered, the difficulty being that any process affecting one 
factor modifies the other as well. Thus, when incubation with acid improves the digestibility of the native protein, we may explain it from the one view-point as due to the destruction of the antitrypsin, and from the other as due to the conversion of the indigestible egg-white into digestible acid-metaprotein. When treatment with chloroform renders the egg-white digestible, we may assume that this is caused either by the removal or destruction of the anti-enzyme, or by the change effected in the chemical properties of the protein.

The simplest assumption is that raw egg-white is attacked with much difficulty by the digestive enzymes. It is not contended that raw starch, agar, collagen, cellulose, and other indigestible substances contain anti-enzymes. Moreover, the existence of such substances has been seriously doubted of late by investigators like Bayliss (1908) and Cohnheim (1912), the latter of whom considers that, "the evidence does not permit us to speak of specific antiferments." Probably the explanation of the behavior of antitryptic substances most in favor at present, is that which postulates an adsorption of the trypsin, the effective concentration of which is thereby reduced.

\section{What Component of Egg-White Is Responsible for Its Peculiar} Behavior in the Alimentary Tract.

\section{The Action of the Individual Proteins of Egg-White.}

The proteins of egg-white were separated from each other according to the method of Osborne and Campbell (1900). Care was taken to have the various fractions as free from each other as possible and each was dialyzed free from ammonium sulfate before being used. The amounts of the various proteins used were equivalent to those contained in the whites of five or six eggs, which amount of egg-white had previously been found sufficient to cause severe diarrhea in the dogs used as subjects.

Globulin.-According to Osborne and Campbell globulin is present in egg-white to the extent of 7 per cent of the total solids. The whites of five or six eggs contain approximately 1.5 to $2 \mathrm{gm}$. of globulin. These amounts of freshly prepared, moist globulin mixed with the usual meal did not affect the dogs in the least and the same was true when quantities four or five times as 
large were ingested. Even $20 \mathrm{gm}$. of purified egg globulin prepared 2 years previously did not perceptibly alter the consistency of the feces, although it was not very well utilized.

Ovalbumin.-The ovalbumin was obtained in fine cyrstals. After being dialyzed it was quickly dried at a low temperature. Osborne and Campbell succeeded in crystallizing 50 per cent of the total proteins in egg-white but consider that all the other fractions contain more or less of this substance. While the actual proportion present is, then, somewhat doubtful, for these experiments it was assumed to be 60 per cent. The whites of five or six eggs would then contain 12.5 to $16 \mathrm{gm}$. of ovalbumin. Fed in these amounts to dogs it caused diarrhea which was more marked when larger amounts were ingested. Its action, however, was not so marked as might be expected from the activity of the native egg-white itself and was also more variable. Thus one dog, for instance, in which diarrhea had been induced several times with raw egg-white failed to react at all to the ovalbumin. Perhaps this is not surprising considering the amount of manipulation necessary to obtain the pure ovalbumin. While the globulin is separating the mixture becomes strongly alkaline from the formation of ammonium hydroxide, and another change-possibly oxidative-is going on as shown by the gradually deepening color of the solution. Later the ovalbumin stands for a long time in contact with acid, is dialyzed for several days, and dried. Osborne and Campbell indeed regard the crystallized substance as different from the original protein and consider that it is probably a combination of the protein with acicl.

Conalbumin.-The amount of uncrystallizable albumin in eggwhite is not definitely known but it is probably from 25 to 35 per cent of the total proteins. In five or six egg-whites there would be 4.5 to $6 \mathrm{gm}$. of conalbumin. Fed in these amounts it generally caused the formation of pasty feces, which effect was increased where the amount ingested was larger. A mixture of ovalbumin and conalbumin in the proportion in which they occur in eggwhite fed to dogs in amounts equivalent to 85 per cent of the total proteins in five or six egg-whites caused diarrhea.

Ovomucoid.-It seems unlikely that ovomucoid is the disturbing protein of the egg-white since it is present in small amount10 per cent according to Hammarsten,- -is unaffected by heating 
in boiling water, and is precipitated unchanged by alcohol, so that it was present in the alcohol precipitates which failed to cause diarrhea. This supposition was confirmed by feeding to dogs ovomucoid prepared as follows. The whites of five or six eggs were diluted with water and the globulin and albumins coagulated by boiling after the addition of a little acetic acid. The filtrate containing the ovomucoid was fed to dogs mixed with the usual meal but did not cause diarrhea.

The albumin fraction, therefore, appears to be the indigestible portion of the egg-white. This is in harmony with the observations of Mendel and Lewis who found that purified ovalbumin fed to dogs in comparatively large amounts caused profuse diarrhea. Vernon (1904) found crystallized albumin to be even more resistant to trypsin than native egg-white. Bainbridge (1911) noted that certain forms of bacteria do not appreciably break down this substance even in the presence of sufficient non-nitrogenous food to insure vigorous bacterial growth. In view of these results it is interesting that the antitryptic action of bloodserum according to Hedin (1904), Cathcart (1904), and Vernon (1908) is associated with the albumin and not with the globulin.

\section{The Digestibility of Duck Egg-White.}

Experiments with the white of the eggs of the Eastern Indian Runner demonstrated that it, too, was indigestible, caused diarrhea, and was poorly utilized. The egg-white of the common fowl, then, is not unique in its exceptional conduct as a foodstuff. The egg of the duck appears to have been little investigated but the white differs in appearance from that of the hen's egg, and Panormow (1906) thought that it contained a special protein not found in other eggs.

\section{The Behavior of Egg-Yolk in the Alimentary Tract.}

When egg-yolk was fed to dogs in any large quantity as part of a meal containing lard and cracker-dust, it usually caused a rather severe digestive disturbance of which vomiting was the main symptom. The vomitus contained much bile, and frequently comparatively large amounts of this liquid were expelled from the stomach. Diarrhea sometimes accompanied this 
vomiting. The subjects were apathetic and had little appetite for several days. These effects were brought about by cooked as well as by raw egg-yolk. The picture of this digestive disorder is thus quite different from that induced by native egg-white.

The regurgitation of bile suggested the fat as the cause of the trouble. Therefore the lard was omitted from the meal with favorable results since no diarrhea or vomiting was then noted. The same end was attained by extracting the fat from the eggyolk by means of ether. The crude yolk-protein, freed from ether, was fed with lard and cracker-meal to dogs, and was inactive. The dogs affected by egg-yolk in the way described seem, then, to have had a low tolerance for fat. The disturbing effect of the yolk is considerably less than that of the white; for while, in one case, the whites of four raw eggs caused diarrhea the same subject ate six raw yolks with impunity.

The egg-yolk and ovovitellin were found to be excellently utilized and there appears to be nothing in the literature to show that they are incligestible. Mendel and Lewis' (1913) experiments showed the excretion of nitrogen after feeding ovovitellin to be the same as that after meat, a result in opposition to that obtained with coagulated and uncoagulated egg-white where the nitrogen excretion was delayed. MeCollum (1909) sustained life in white rats for 18 weeks on nothing but egg-yolk with no unfavorable results, while it may be recalled that Maignon, Knapp, and von Knieriem could not keep dog:s, rats, or mice alive on egg-white alone. Laschtschenko (1909) found that bacteria thrived well on egg-yolk, that it does not possess germicidal properties, and cuts down the bactericidal action of the egg-white.

\section{SUMMARY.}

Raw egg-white is found to be a decidedly indigestible substance. It may cause diarrhea in dogs, rats, rabbits, and man when ingested in any large quantity. Its utilization by the body is poor since it is used only to the extent of 50 to 70 per cent. Subjects can acquire a certain tolerance for the native protein after ingesting it for several days so that it no longer causes diarrhea and is somewhat better utilized.

Raw egg-white can be made digestible through coagulation 
by heat; by precipitation with alcohol, chloroform, or ether; by incubation with dilute acids or alkalies; by partial digestion by pepsin; by conversion into alkali-metaprotein.

The indigestibility of native egg-white probably lies either in its antitryptic content or in its chemical constitution. Its physical texture appears to play a minor part in its behavior.

Of the individual proteins constituting egg-white, the albumin fraction appears to be the indigestible component.

The whites of the hen's egg and cluck's egg act alike in causing diarrhea and in being poorly utilized.

Egg-yolk either raw or cooked is excellently utilized. It sometimes causes digestive disturbances in dogs, apparently because of its high fat content.

A review of the literature shows that dietitians have relied, in general, upon the early observations of Beaumont as support for the use of raw eggs: These observations were in the main exact; but, so far as the digestibility of raw egg-white is concerned, were misinterpreted.

In current dieto-therapy raw whole eggs, raw egg-white, and albumin-water are extensively prescribed. There appears to be little in their conduct as foodstuffs, however, to warrant such faith in their nutritive value or ease of assimilation.

In conclusion it is a pleasure to thank Dr. Lafayette B. Mendel for his kindness and helpfulness during the course of this work.

\section{REFERENCES.}

Abderhalden, E., and Pettibone, C. J. V., Über den Einfluss des physikalischen Zustandes von Proteinen auf die Raschheit ihres Abbaues durch Fermente, Z. physiol. Chem., 1912, lxxxi, 458.

Atwater, W. O., and Langworthy, C. F., A digest of metabolism experiments, U. S. Dept. Agric., Office of Exp. Stations, Bull. 45, 1898.

Bainbridge, F. A., The action of certain bacteria on proteins, J. Hyg., 1911, xi, 341 .

Bayliss, W. M., The Nature of Enzyme Action, London, 1908.

Bayliss, W. M., and Starling, E. H., The mechanism of pancreatic secretion, J. Physiol., 1902, xxviii, 325.

Beaumont, W., Experiments and Observations on the Gastric Juice, and the Physiology of Digestion, Plattsburg, 1833.

Bizarro, A. H., On the influence of preliminary heating upon peptic and tryptic proteolysis, J. Physiol., 1913, xlvi, 267. 
Brüno, G. G., and Klodnizki (quoted from: Babkin, B. P., Die äussere Secretion der Verdauungdrïisen, Berlin, 1914).

Cannon, W. B., The passage of different food-stuffs from the stomach and through the small intestine, Am. J. Physiol., 1905, xii, 387.

Cathcart, E. P., On the antitryptic action of normal serum, J. Physiol., 1904, xxxi, 497.

Chittenden, R. H., Joslin, E. P., and Meara, F..S., On the ferments contained in the juice of the pineapple, Tr. Connecticut Acad. Arts and Sc., 1892, viii, 281.

Chittenden, R. H., On the proteolytic action of bromelin, the ferment of pineapple juice, J. Physiol., 1894, xv, 249.

Cohnheim, O., Enzymes, New York, 1912.

Cramer, W., On the assimilation of protein introduced parenterally, $J$. Physiol., 1908, xxxvii, 146.

Dakin, H. D., and Dudley, H. W., The action of enzymes on racemized proteins and their fate in the animal body, J. Biol. Chem., 1913, $\mathrm{xv}, 271$.

Delezenne, C., and Pozerski, E., Action empêchante de "l'ovalbumine crue" sur la digestion tryptique de "l'ovalbumine coagulée," Compt. rend. Soc. biol., 1903, Iv, 935.

Falta, W., Studieren über den Eiweissstoffwechsel, Deutsch. Arch. klin. Med., 1906, lxxxvi, 517.

Falta, W., and Noeggerath, C. T., Fütterungsversuche mit künstlicher Nahrung, Beitr. chem. Phys. u. Path., 1905, vii, 313.

Frank, P., The digestibility of white of egg as influenced by the temperature at which it is coagulated, J. Biol. Chem., 1911, ix, 463.

Frank, F., and Schittenhelm, A., Über die Brauchbarkeit tief abgebauter Eiweisspräparate für die Ernährung, Therap. Monat., 1912, xxvi, 112.

Gompel, M., and Henri, V., Etude du ralentissement que produit l'albumine d'oeuf crue sur la digestion tryptique de l'albumine coagulée, Compt. rend. Soc. biol., 1905, lviii, 457.

Hamburger, F., Zur Frage der Immunisieruug gegen Eiweiss, Wien. klin. Woch., 1902, xv, 1188.

Hammarsten, O., A Textbook of Pliysiological Chemistry, New York, 6th edition, 1912 .

Hammerl, H., Kermanner, F., Moeller, J., and Prausnitz, W., Untersuchungen über das Verhalten animalischer und vegetabilischer Nahrungsmittel im Verdauungskanal, Z. Biol., 1897, xxxv, 287.

Hedin, S. G., Investigations on the proteolytic enzymes of the spleen of the ox, J. Physiol., 1904, xxx, 155.

Hedin, On the antitryptic action of serum albumin, J. Physiol., 1905, a, xxxii, 390 .

Hedin, Action of trypsin, J. Physiol., 1905, b, xxxii, 468.

Hedin, Trypsin and antitrypsin, Biochem. J., 1906, a, i, 474.

Hedin, An antitryptic effect of charcoal, Biochem. J., 1906, b, i, 484.

Hedin, Über versehiedenartige Hemmung der tryptischen Verdauung, $Z$. physiol. Chem., 1907, lii, 412. 
Horowitz, Contribution ì l'étude des moyens de défense de l'organisme contre l'invasion microbiemne, Thèse de Paris, 1902, abstr. in Jahresber. path. Mikroorgan., 1903, xix, 984.

Jobling, J. W., and Petersen, W. F., A study of the ferments and antiferments of the body, Bull. Johns Hopkins Hosp., 1915, xxvi, 356.

Jonese1, D., UUber eine eigenartige Verdauung des Hühner- und Serumeiweiss dureh Papain, Biochem. Z., 1907, ii, 177.

Klug, F., Beiträge zur Pepsinverdauung, Arch. ges. Physiol., 1897, lxv, 330.

Knapp, P., Experimenteller Beitrag zur Ernährung von Ratten mit künstlicher Nahrung, Z. exp. Path. u. Therap., 1908-09, v, 147.

Kolpakeha (quoted from Atwater and Langworthy), Phiziol. Sbornik. Charkoff, 188s, i, 56.

Kossowiez, A., Die Zersetzung und Haltbarmachung der Eier, Wiesbaden, 1913.

Lamson, G. H., Infection and preservation of eggs, Storrs Agric. Exp. Station, Bull. 55, 1909.

Laschtschenko, P., Über die keimtötende und entwicklungshemmende Wirkung von Hühnereiweiss, Z. Hyg., 1909, lxiv, 419.

LeClerc, J. A., and Cook, F. C., Metabolism experiments with organic and inorganic phosphorus, J. Biol. Chcm., 1906-07, ii, 203.

London, E. S., and Sulima, A. T., Zum Chemismus der Verdauung im tierisehen Körper, Z. physiol. Chem., 1905, xlvi, 209.

Long, J. H., and Johnson, W. A., Activity and stability of certain ferments. II, J. Am. Chcm. Soc., 1913, xxxv, $118 s$.

Maignon, F., Rôle des graisses dans l'utilisation de l'allbumine alimentaire, Compt. rend. Soc. biol., 1912, lxxii, 1054.

Mauer, The bacteriology of eggs and egg products, Kansas State Agric. Coll., Exp. Station Bull. 180, 1911.

Maxwell, The relation of salivary to gastric digestion, Biochem. J., 1915, ix, 323.

MeCollum, E. V., Nuclein synthesis in the animal body, Am. J. Physiol., 1909-10, xxv, 127.

Mendel, L. B., and Fine, M. S., The utilization of proteins, J. Biol. Chem., $1912, x i, 5$.

Mendel, L. B., and Lewis, R. C., Rate of elimination of nitrogen as influenced by diet factors, J. Biol. Chem., 1913-14, xvi, 55 .

Mendel, L. B., and Rockwood, E. W., On the absorption and utilization of proteins, Am. J. Physiol., 1905, xii, 336.

Mendel, L. B., and Rose, W. C., Experimental studies on creatine and creatinine, J. Biol. Chem., 1911-12, x, 213.

Oertel, M. J., Ueber Ernährung mit Hühnereiern, Munich, 1883.

Okada, S., On the secretion of bile, J. Physiol., 1914-15, xlix, 458.

Oppenheimer, C., Über das Schicksal der mit Umgehung des Darmkanals eigneführten Eiweissstoffe im Tierkörper, Beitr.chem. Phys. u. Path., 1904, iv, 263.

Osborne, T. B., and Campbell, G. F., The protein constituents of eggwhite, J. Am. Chem. Soc., 1900, xxii, 422. 
Osborne, T. B., and Mendel, L. B., Feeding experiments with isolated food-substances, Carnegie Institution of Washington, Publication No. $156,1911$.

Osborne and Mendel, The contribution of bacteria to the feces, J. Biol. Chem., 1914, xviii, 177.

Panormow, A. A., Über einige Eigenschaften der Albumine im Eiweiss der Enteneier, Biochem. Centr., 1906, v, 171.

Pawlow, I. P., The Work of the Digestive Glands, London, 1902.

Pennington, M. E., A chemical and bacteriological study of fresh eggs, J. Biol. Chem., 1909-10, vii, 109.

Rettger, L. F., The bacteriology of the hen's egg, with special reference to its freedom from microbic invasion, Ccntr. Bakteriol., 2 te Abt., 1913-14, $\mathrm{xxxix}, 611$.

Rettger, L. F., and Sperry, J. A., The antiseptic and bactericidal properties of egg-white, J. Med. Research, 1912, xxvi, 55.

Röhmann, F., Über die Ernährung von Mäusen mit einer aus einfachen Nahrungsstoffen zusammengesetzten Nahrung, Biochem. Z., 1914. lxiv, 30 .

Sachs, F., Über die Verdauung von rohem Hühnereiweiss durch Papain, Z. physiol. Chem., 1907, li, 488.

Steinitz, F., Ueber das Verhalten phosphorhaltiger Eiweisskörper im Stoffwechsel, Arch. ges. Physiol., 1898, lxxii, 75.

Stiles, G. W., and Bates, C., A bacteriological study of shell, frozen, and desiccated eggs, U. S. Dept. Agric., Bureau of Chem., Bull. 158, 1912.

Talarico, J., De l'influence de la cuisson sur la digestibilité tryptique de l'albumine d'oeuf, Compt. rend. Soc. biol., 1910, lxviii, 662.

Tsuboi, J., Ueber die Stickstoffausscheidung aus dem Darm, Z. Biol., 1897, xxxv, 68 .

Tsuchiya, I., Ueber das Auftreten des gelösten Eiweisses in den Füces Erwachsener, Z. exp. Path. u. Therap., 1909, v, 455.

Vernon, H. M., The protective value of proteids and their decomposition products on trypsin, J. Physiol., 1904, xxxi, 346.

Vernon, Intracellular Enzymes, London, 1908.

Vogt, H., Der zeitliche Ablauf der Eiweisszersetzung bei versehiedener Nahrung, Beitr. chem. Phys. n. Path., 1906, viii, 409.

Von Knieriem, W., Ueber die Verwerthung des Cellulose im thierischen Organismus, $Z$. Biol., 1885, xxi, 67.

Wiley, H. W., A preliminary study of the effects of cold storage on eggs, quail, and chickens, U. S. Dept. Agric., Bureau of Chem., Bull. 115, 1908.

Wolf, C. G. L., Die Ausschiedungszeit von Stickstoff, Schwefel, und Kohlenstoff nach Aufnahme von Eiweisssubstanzen und ihren Spaltungsprodukten. II, Biochem. Z., 1912, xl, 234. 



\title{
THE USE OF RAW EGGS IN PRACTICAL DIETETICS.
}

\author{
By W. G. Bateman, Ph.D., \\ MISSOULA, MONTANA. \\ (From the Sheffield Laboratory of Physiological Chemistry in Yale University, \\ New Haven, Comn.)
}

Durisg the past fifteen years evidence has been gradually accumulating which shows that raw egg-white occupies an exceptional position among native protein foodstuffs. Pawlow (1902) observed that this substance has only a feeble ability to stimulate a flow of gastric juice. It acted in this way only as so much water. Cooked egg-white, on the contrary, calls forth an abundance of juice and unites easily with the hydrochloric acid. On account of the scanty supply of secretion which it induces the raw protein has little opportunity to be digested, but this slender chance is still further diminished by another unusual property. Beaumont (1833), during his famous experiments on Alexis St. Martin, was the first to note that native egg-white left the stomach very rapidly in comparison to other foods, including cooked egg-white itself. Indeed, this substance spent a shorter time in the stomach than any other Beaumont investigated. This observation has more recently been confirmed by Cannon (1904) and by London and Sulima (1905). The former found that the egg-white passed through the pylorus at a rate comparable to that of the carbohydrates, which are among the first foodstuffs to enter the intestine after ingestion. Proteins leave the stomach slowly and egg-white was the only exception noted among those investigated. London and Sulima found that this hasty exit from the stomach was most striking. A few moments after ingestion the egg-white escaped in large gushes through a pyloric fistula. During its stay in the stomach it retains its alkaline reaction and passes into the intestine, for the most part entirely unchanged. After feeding a $\operatorname{dog}$ native egg-white these workers recovered large amounts unchanged from a fistula as far down the canal as the ileum.

But even this does not exhaust the means by which raw eggwhite escapes gastric digestion, for Abderhalden and Pettibone (1912) and Bizarro (1913) discovered that it offers considerable 
resistance to the action of pepsin. If, however, the egg-white is coagulated it is more readily acted upon by the pepsin, and proteolysis proceeds further.

We may picture this native protein then as quickly leaving the stomach, accompanied by scanty amounts of gastric juice and little altered by pepsin. This peculiar behavior is consistently carried on in the intestine. Bruno and Klodnizki (1914) and Okada (1915) showed that little or no bile was passed into the intestine after the ingestion of raw egg-white, whereas the same material cooked always caused a good flow of bile.

Once in the intestine the native egg-white continues to oppose the digestive enzymes, for it has remarkably strong antitryptic properties. The trouble is not that trypsin is unable to act upon the protein but that the rate of action is so slow. Bayliss (1908) found that it required seventy hours for the digestion of the raw material to equal that of the cooked, all other conditions being the same in the two cases. Indeed, the trypsin appears not to change the egg-white at all. Vernon (1904) found the antitryptic action to be more marked with this protein than with any other. Hedin (1907), Cohnheim (1912), Abderhalden and Pettibone (1912), Long and Johnson (1913), and Bizarro (1913) have all demonstrated the strong antitryptic action of egg-white. Not only does it resist digestion itself, but it prevents the digestion of other easily digested proteins, as observed by Delezenne and Pozerski (1903), Vernon (1904), Compel and Henri (1905), and Hedin (1907). This suggests that the true cause of both facts is that the colloidal egg-white absorbs the trypsin, thus cutting down its activity in much the same way as the charcoal in the experiments of Hedin $(1906$ b). Recently it has been shown by Maxwell (1915) that boiled starch absorbs pepsin and so hinders its activity.

In view of both its antipeptic and antitryptic action it is interesting to note that other proteolytic enzymes are also unable to successfully cope with this native protein. Chittenden, Joslin and Meara (1892), and Chittenden (1894) showed that raw eggwhite was much more poorly digested than coagulated egg-white by bromelin, the proteolytic enzyme present in the pineapple. Jonescu (1907) and Sachs (1907) found that papain was also practically unable to act upon native egg-white.

Preliminary heating of the egg-white greatly increases its digestibility by trypsin. Talarico (1910) found that there was no effect, however, until the temperature reached $70^{\circ}$, after which there was an orderly liberation of amino-acids up to $130^{\circ}$. Frank (1911) also found cooked egg-white to be better digested than raw, the optimum temperature in his experience being $70^{\circ}$ to $75^{\circ}$. Bizarro (1913) considered the best temperature for this preliminary heating to be $S 0^{\circ}$. Abderhalden and Pettibone (1912) and Long and Johnson (1913) made similar observations. 
This brief review of its properties shows that native egg-white offers such obstacles to digestion as to place it in an exceptional position among the proteins. This raises the question as to how the body handles such a substance. Very little upon this point has, up to the present, been recorded, although raw eggs and eggwhite have enjoyed a great vogue as the mainstay of various diets, especially for the sick. Steinitz (1898) noted incidentally that raw egg-white caused vomiting and diarrhea in $\operatorname{dogs}$, but this interesting observation remained unnoticed. When the same facts were observed again by Mendel and Lewis (1913) they led to an extended study by the author, carried out during the past year, the details of which have been published elsewhere. This showed native egg-white to be a decidedly indigestible subsubstance. When fed to dogs in any considerable quantity it invariably caused diarrhea and sometimes induced vomiting. The severity of the diarrhea depended largely upon the amount of material ingested, but also, to a less extent, upon the individual susceptibility of the subject. With dogs of 5.5 to $7 \mathrm{kilos}$ in.weight four or five egg-whites were sufficient to cause more or less severe diarrhea. Even the whites of two eggs often caused softening of the feces. The stools were abnormal in character, very offensive in odor, and often contained much mucus. After the ingestion of even small amounts of native egg-white the latter could be recovered unchanged in small quantity from the stools, and when the amount ingested was large the proportion of coagulable protein in the feces was correspondingly increased.

Even when the feces appeared normal undigested egg-white could usually be recovered. In this connection, Tsuchiya's (1908) statement that albumin is never found in normal feces is pertinent.

After eating enough egg-white to give rise to diarrhea the dogs usually lost weight. In a few cases small intestinal hemorrhages were observed. Occasionally samples of urine obtained by catheterization were found to contain small amounts of protein. In all these reactions there was found much variation in the sensitiveness of the subjects, for sometimes a large dog was more easily affected than a small one by the same amount of protein.

It made little difference with the action of the egg-white whether it was eaten alone or mixed with other food. In the latter case the diarrhea was later in appearing. The presence in the food of a substance able to cause a good flow of gastric juice-meat extract for example-had no effect upon the time of appearance or severity of the diarrhea.

It was soon noticed that when the raw protein was fed for several days in succession its ill effects gradually waned. The time necessary for the abatement of the diarrheal action varied from three to five days. If now the ingestion were continued there ensued a period of alternate days of diarrhea and constipa. 
tion, after which the egg-white ceased to exert any marked action. The tolerance thus developed lasted for a short time even after the feeding of the uncooked material was discontinued. This recalls the tolerance acquired by $\operatorname{logs}$ who receive peritoneal injections of raw egg-white. Cramer (1908), Hamburger (1908), and Oppenheimer (1904) have observed that under such conditions the dogs utilized part of the protein and excreted the rest in the urine. After repeated injections the quantity used rose gradually. It might be supposed that all proteins would appear, at least in part, in the urine after injection intraperitoneally, but Mendel and Lockwood (1904) have shown this not to be the case with edestin and excelsin.

Native egg-white was found poorly utilized. In large doses from 30 to 50 per cent. of that ingested was wasted by being ejected with the feces. After the dogs had grown to tolerate this material it was better utilized, but even in these cases the best figure was about S5 per cent. When Mendel and Lewis (1913) fed this substance to $\operatorname{logs}$ only about half of the nitrogen in the meals appeared in the urine for the following twenty-four hours as contrasted with almost all when meat, casein, and other proteins were fed instead of the egg-white. Steinitz (1898) reported unchanged egg-white in the feces in considerable quantities. Vogt (1906) and Falta (1906) found that the nitrogen in uncooked egg-white superimposed upon a standard diet was excreted in the urine much more slowly than that ingested in the form of other proteins.

Drying the egg-white at low temperatures did not abate its diarrheal activity nor improve its utilization. Neither did long standing. Falta (1906) also made experiments, using desiccated material, and found in three cases a utilization of 80 per cent., so per cent., and 61 per cent. respectively. LeClerc and Cook (1906) found the same substance very poorly utilized.

When dogs ate cooked egg-white in place of the native or desiccated protein they did not have diarrhea and the material was excellently utilized, the utilization being in the neighborhood of 90 per cent. When raw and cooked egg-white were fed on alternate days or periods the differences in the utilization and in the nitrogen balance were striking.

Experiments were made to show at what temperature the change in digestibility became effective. By heating for thirty to fortyfive minutes in a double boiler with constant stirring the egg-white suffered little impairment of its activity in causing diarrhea up to $55^{\circ}$. Above this the activity is considerably decreased and disappears entirely at $70^{\circ}$. It should be noted that above $55^{\circ}$ coagulation begins and at $70^{\circ}$ the protein is entirely coagulated, but is very soft and jelly-like in texture.

In order to show that dogs did not have an exceptional inability 
to digest native egg-white, experiments similar to the above were made, using rats and rabbits as subjects. These had in both cases the same results. Both rats and rabbits had diarrhea with consequent poor utilization of the protein. The hardy rats, however, were less sensitive than the other animals. That this native protein sustains life in rats poorly in comparison to others is the general conclusion drawn from the work of Falta and Noeggerath (1906), Knapp (1908), Maignon (1912), and Frank and Schittenhelm (1912). Von Kinieriem (1SS5) and Röhmann (1914) reached the same decision from work with mice as subjects. Osborne and Mendel (1911), on the contrary, kept rats growing well on rations containing cooked egg-white as sole protein for as long as one hundred and seventy days. Von Knieriem (1SS5) found that desiccated egg-white caused rabbits to pass very soft and abnormal feces containing much unchanged egg-white. Mendel and Rose (1911) found it impossible to feed any large quantity of raw egg-white to rabbits without inducing diarrhea.

No other native proteins are known to act in the alimentary tract in the manner brought out by these experiments. On account of the importance of the subject from the stand-point of dietetics it was of interest to determine how raw egg-white comported itself when ingested by man. The experiments described below lead to the same conclusions already formulated.

The first group of subjects included a number of men and women partaking of a diet consisting largely of raw eggs and milk for the purpose of increasing weight.

C.ASE I.-Subject O. B. This was a man, aged twenty-five vears, who took two to three raw eggs beaten up in milk three times a day. During the first three days there was rather severe diarrhea and general malaise and after that regular stools of soft consistency. The subject had previously been somewhat constipated.

CASE II.-Subject D. S. was a man, aged forty years, who also took two raw eggs beaten up in milk three times a day. He did not experience diarrhea, but did have regular stools sometimes twice a day, whereas before beginning the diet he had had somewhat obstinate constipation. He drank a large quantity of milk which generally would tend to prevent diarrhea.

C.ASE III.-Subject M. R., a woman, aged twenty-five years, ate six to eight raw eggs per day. The first few days there was extensive diarrhea followed for some time by irregular movements, consisting usually of soft material.

CASE IV.-Subject M. H., a young woman, aged twenty-two years, who ate two raw eggs at night and the same number in the morning. There was no decided diarrhea, but previous constipation was overcome and the stools were soft. This subject complained of some intestinal discomfort. 
CASE V.-Subject D. G., a woman, aged thirty-five years, took two or three raw eggs in milk three times a day. In this case there was diarrhea for two days, although not severe. This was followed by a day without a stool, after which the bowels moved regularly every day. There had been no previous constipation.

CASE VI.-A man, aged about thirty-five years, took each night before retiring two raw eggs in whisky. On almost every such occasion he suffered much intestinal discomfort, accompanied with colic-like pains. Considering raw eggs to be "bland" and the whisky beneficial he did not discontinue the treatment for some time.

Another group of subjects ate only the whites of raw eggs experimentally.

CASE I.-Subject D. S., a young woman, aged eighteen years, was unaffected by eating the whites of two eggs per day. When the number was doubled, diarrhea ensued accompanied by discomfort and some trouble with intestinal gases.

CASE II.-Subject B. B., aged thirty years, remained unaffected by eating every morning the whites of two to four eggs. She did notice discomfort and accumulation of gas. When the number was increased to six per day the subject complained of malaise and took an aversion to the diet. There was flatulence but no diarrhea.

CASE III.-Subject A. B., a child, aged three years. One-half of a raw egg-white ingested each day led to such laxness that the experiment was discontinued after the third day. The diarrhea, then, disappeared at once.

CASE IV.- Subject J. B., aged five years, was, on the contrary, quite unaffected by the same amount of egg-white as was given the last subject.

CASE V.-Subject IV. B., a man, aged thirty years, was found quite unsusceptible to the native egg-white, since two to six whites failed to cause any noticeable change in the feces. When half a dozen eggs were eaten at once he experienced decided discomfort, associated with flatulence. An analysis of the stool for nitrogen showed the protein ingested to be only 85 per cent. utilized. Even eight to nine raw whites eaten at one time did no more than soften the feces, but the utilization was still poorer than before, being only 77 per cent. At no time was there any protein in the urine.

CASE VI.-Subject L. M., aged twenty-five years, ate the whites of six raw eggs every third day. On each occasion the stool was soft and unformed.

Falta (1906) found this material to be utilized by man to the extent of 70 per cent. Wolf (1912) reported a still lower value, namely, 50 per cent. In the latter case the feces were of soft consistency although no diarrhea was observed. There was over twice as much nitrogen in the feces when the raw egg was in the diet as when the food contained the same amount of nitrogen in the form of other proteins. On one day there was more nitro- 
gen in the feces than in the urine. The latter did not contain albumin.

Hamburger (1902) and Cramer (190S) claim that albuminuria follows the ingestion of large doses of native egg-white by man. Oertel (1883) had not been able to find albumin in the urine of either dogs or men after the ingestion of large quantities or raw or half-cooked egg-white. Neither did this material cause an increase in excreted albumin in preëxisting albuminuria. Another aspect of this debated problem will be considered later.

It is a matter of common experience that cooked egg-white has not been known to cause any exceptional digestive effects, and is well utilized. Rubner (1879), who seems to be the sole investigator to have fed a subject on cooked eggs only, found the utilization to be 97 per cent. Cathcart and Green (1913) found a delay in the excretion of nitrogen after superimposition of both native and coagulated egg-white, but the delay appears greater in the sulphur than in the nitrogen elimination. 'These authors and Wolf (1912), who noticed the same facts, believe that the sulphur complexes in the uncoagulated egg-white have power to withstand the digestive enzymes.

Raw egg-white can be made digestible by other means than heating at $70^{\circ}$. This result can be brought about by incubation with dilute acids and alkalies at $37^{\circ}$; by precipitation with alcohol, chloroform, or ether; by partial digestion with pepsin, and by conversion into alkali metaprotein.

Egg-white is not a homogeneous substance, but consists of at least four components-ovoglobulin, ovalbumin, conalbumin, and ovomucoid. These were separated according to the method of Osborne and Campbell (1900). When fed to dogs the albumin fraction proved to be the indigestible constituent, a result in harmony with the observations of Mendel and Lewis, who found that purified ovalbumin caused profuse diarrhea when fed to dogs. Vernon (1904) states that crystallized albumin is even more resistant to trypsin than native egg-white.

All the experiments so far described were made with egg-white from the egg of the common fowl. That it is not unique in its unusual behavior in the alimentary tract was shown when the egg-white from the egg of the duck was found to act in exactly the same manner.

In contrast to egg-white, egg-yolk was found to be well digested and utilized. There appears to be nothing in the literature to suggest that the latter is indigestible. Mendel and Lewis's (1913) experiments showed the excretion of nitrogen after feeding ovovitellin to be the same as that after meat, a result in opposition to that obtained with both coagulated and uncooked egg-white. In the author's experiments the feeding of egg-yolk either cooked or raw in any quantity of dogs usually caused a rather severe digestive 
disturbance, of which vomiting was the main symptom. The vomitus contained much bile and sometimes this liquid was alone expelled from the stomach. This suggested that the high fat content of the yolk was the cause of the trouble. This assumption was correct, for when the fat was extracted the residue of crude ovovitellin was eaten by dogs with no untoward effects.

These experiments show, then, that raw egg-white is a decidedly indigestible substance. It may cause diarrhea and vomiting when ingested in any large quantity. Its utilization by the body is poor, since it is used only to the extent of from 50 to 70 per cent. What bearing have these facts upon practical dietetics?

It is difficult to say to what extent raw eggs are ordinarily used. Since there is a wide-spread idea that they are especially digestible and very nutritious, one might expect their use to be common. There is no doubt that this is so when the diet in disease is considered, for raw eggs appear to play an important part in systems of dietetics for the sick. It is likely that Beaumont's (1833) observations gave the first impetus to this dieto-therapeutic movement. According to his views digestion takes place in the stomach and absorption in the intestines. The criterion of digestibility was the time a food remained in the stomach, the assumption being that it passed the pylorus only when properly prepared by digestion for ensuing absorption through the intestinal mucosa. Since native egg-white left the stomach more rapidly than any other food the conclusion seemed obvious that it is a very readily digested substance. Beaumont says:

"Albumin if taken into the stomach either very slightly or not at all coagulated is perhaps as readily chymified as any article of diet we possess. If coagulated it experiences a very protracted digestion. In the first case the albumin becomes finely coagulated and divided in the stomach."

While the fact that raw egg-white does remain in the stomach only a short time is true, the interpretation of the fact was erroneous. These experiments of Beaumont, the first of their kind, attracted much attention and became widely known. The earlier writers on dietetics based their advice in many details upon his work. Chambers in his Manual of Diet (1875), after quoting a table of Beaumont's showing the times spent in the stomach by raw eggs and eggs cooked in various ways, says,

"It may be observed that this is just the order in which they are tasty-that is to say, the degree in which they come with facility into contact with the sensory nerves distributed through the mucous membrane-so that duty and pleasure here, as usually in natural operations, become one."

To such a school nature is always right; it would not be thought possible for her to be so mistaken as to allow albumin to leave the stomach practically undigested. 
Although these early views on digestion are no longer supported by such arguments they still appear to be accepted almost unquestioned. In 1906 a Farmers' Bulletin of the United States Department of Agriculture quotes Beaumont's work and helps to spread the impression that raw eggs are very easily digested, since they are "chymified" in one and a half to two hours as against three for soft-boiled eggs. The figures for "artificial digestion," which approximated bodily conditions as closely as possible, are even more impressive, since it appears that it requires eight hours for the digestion of hard-boiled eggs, six hours for soft-boiled eggs, and only four hours for raw eggs. This bulletin, which has been extensively circulated, gives also the results of experiments which show that cooked eggs are thoroughly digested. Still more recently in Practical Dietetics for Nurses, Pattee (1910) quotes, "Haif subtilized to chyme the liquid food readiest obeys the assimilating powers." Egg-white is then listed as a liquid food and the proper conclusion thus drawn. This notion of the easy assimilation of liquid foods is often mentioned by writers on dietary topies in their discussion of egg-white, and it is taken for granted that such a substance offers little resistance to the digestive juices. How far astray such an assumption may lead one has already been shown.

In the larger and more recent text-books on dietetics the use of raw eggs is generally recommended. Thompson, whose book Practical Dietetics is widely used and much quoted, says on this topic:

"Whole raw eggs are very popular in dietetics at present and are often prescribed when a nutritious, highly concentrated food is desired, as in cases of tuberculosis, some forms of anemia, and various wasting diseases; sometimes from eight to ten or twelve are given daily if they can be digested."

Egg albumen is said to be well absorbed and many recipes are given for preparing albumen water in a palatable form. It is stated, without naming Beaumont, that "a raw egg is ordinarily" digested in the stomach in one and a half hours, but a baked egg requires from three to four hours."

In Diet in Health and Disease, by Friedenwald and Ruhräh (1913), raw eggs are still more strongly recommended. These authors state:

"In various diseases accompanied by loss of flesh and strength, raw eggs in large numbers are prescribed, as many as twenty-four eggs being given in twenty-four hours. Egg albumen is best absorbed when eaten raw. Eggs beaten up in milk are.very useful for the diet of the aged when there are diminished powers of digestion. Raw eggs sometimes disagree but this is more often due to faulty preparation than to any real egg idiocyncrasy. In tuberculosis raw eggs are of the greatest value; six to twenty-four whites may be given daily." 
These writers-Thompson, Friedenwald and Ruhräh, Pattee, Winthrop (1899) and others-advise raw eggs as part of the diet in the treatment of many diseases, such as typhoid, diphtheria, gastric ulcer, tuberculosis, appendicitis, gastritis, chronic indigestion, etc. We read that "In fevers albumen water helps to supply wasted tissue albumin;" that "Raw eggs in consumption are full of nutrition and very assimilable;" that "Albumen water is utilized by infants, being found very useful in disorders in which some nutritious and easily assimilated food is needed." It is more surprising to find raw egg-white apparently advised in diarrhea and contra-indicated in constipation; to find raw eggs and albumen water prescribed in dysentery, in chronic cases of which "egg albumen and beef juice form the main part of the diet." Again, it is often stated that raw egg-white can be retained or "kept on the stomach" when nothing else can. This is not really true, since it leaves the stomach rapidly, but in a sense contrary to that meant!

In the treatment of typhoid most writers are agreed that indigestible food should not be fed and that "those causing the least intestinal debris" are the best; yet they all unite in advising raw egg-white in the diet. In the current therapy of gastric ulcer albumen water is frequently used, with the object of taking up the excessive acid. Insofar as it calls forth no more gastric secretion its use may be beneficial, but considering the speed with which it escapes through the pylorus its efficiency in removing acid already present is problematical. One writer says: "The egg-albumen should be prepared in such a manner as to require the least possible expenditure of force in digestion." Cannon (1904) has shown that the intestine expends more motor activity upon the absorption of the carbohydrates than upon that of the fats or proteins. Raw egg-white, however, acts like a carbohydrate in this respect. Another author states that native egg-white is especially valuable for those with a "weak digestion." All the evidence gathered in this paper tends to show that the substance in question requires an exceptionally "strong digestion" if it is to be utilized.

The most whole-hearted advocate of raw eggs appears to be Dr. Ely (1903), who, in "The Fable of the Egg," shows himself a bold practitioner of his own ideas. Again, Beaumont is quoted with nothing to show that anything has been added to the subject in the eighty years since his observations. The number of eggs advised and administered may seem "fabulous," as the author admits. One patient ate 3006 raw eggs in a year while another partook of 5475 in the same time, the latter being "an exemplary subject as to eggs." It is further stated:

"Some moral force is necessary on the part of patient, nurse, and doctor to overcome a repugnance to the treatment. It is to be understood that in every instance they [eggs] have been used for their supporting and restorative influence. Although some 
patients have died while taking eggs I can think of no case in which death was due to their liberal use. If you give eggs to your patients do not be chicken-hearted in their employment. Do not fear the production of albuminuria from the ingestion of a large amount of egg albumen. Notwithstanding all possible efforts, nausea and vomiting and diarrhea may often be produced and the physician may be thwarted in his object. He will then try the whites of eggs alone. I have given the whites of forty-eight eggs daily for many days to a patient in the critical stages of typhoid fever. Please remember that I am not advocating a fad, specific, or 'cure-all.' I would urge that in some chronic cases of exhausted nerve centers, and in those acute, critical cases that tax resources for maintaining life, they [doctors] should throw away their tonics and possibly stimulants and should gradually lead the stomachs of their patients up to the egg-an-hour practice."

Enough has been quoted, perhaps, to show the reasons hitherto underlying the advocacy of raw eggs. The results of the present study show these reasons to be not well supported and indicate that the use of raw egg-white is decidedly inadvisable. A substance which fails to stimulate a flow of gastric juice and is antipeptic, which hurries from the stomach, calls forth no flow of bile, and strongly resists the action of trypsin, which is poorly utilized and may cause diarrhea, has evidently little to recommend it as a foodstuff of preference for the sound person, let alone for the invalid. And when the native protein needs only to be coagulated at $70^{\circ}$ in order to obviate almost all the effects mentioned, there appears still less reason for using it uncooked. Other considerations strongly support this conclusion. For instance, Stokvis (1864) declared that raw egg-white eaten in quantity is absorbed undigested and excreted in the urine, doing thereby some damage to the renal epithelium. For a number of years this work was disputed by some and confirmed by others. Áscoli (1902) clarified the situation somewhat by stating that the alimentary albuminuria is not generally manifested by sound persons but usually is by the sick. Besides his own observations he cites other investigators who found that small kidney lesions were caused in this way. The amounts of egg used by Ascoli were not unduly large. The work of Hamburger, Oppenheimer, and Oertel on this topic has already been mentioned. It should be stated that the subject is still a debatable one.

It is true that fairly large amounts of raw egg-white need to be ingested for the abnormal digestive effects to be made manifest; but even if small quantities are used, certain disadvantages may follow. The indigestible protein may reach the large intestine and there become a good pabulum for the putrefactive bacteria. Or mixed with other foods it may retard the digestion and lower the utilization of other proteins. Again, it seems more than a 
coincidence that of all the common proteins egg-white is the most indigestible and at the same time the most common cause of anaphylaxis. According to the latest views on this subject, as stated by Wells (1914), anaphylactic intoxication is caused by the entrance into the blood of intact, foreign protein molecules. If this be so, it would appear that egg-white is a substance peculiarly apt to be the agent in allergy. It leaves the stomach practically unchanged, so that in the intestine it may be absorbed still intact or only slightly altered. The strong antitryptic action it possesses leads to the same danger. Lately, Tan Alstyne (1913) has shown that egg-albumen can enter into the circulation unaltered and is excreted in the urine. In order to cause anaphylaxis it appears unnecessary that large amounts should enter the blood, for Wells (1914) has shown that in guinea-pigs sensitivity has been produced with one twenty-millionth of a gram $(0.00000005 \mathrm{gm}$.) of crystallized ovalbumin and fatal results are obtained after sensitization with one millionth of a gram $(0.000001 \mathrm{gm}$.). In fact, small amounts are frequently more effective than large. It may be argued that cleavage products of any protein may be absorbed in small amount. This is true; but Wells has found that the protein molecule loses its anaphylactic properties as soon as it is altered to any extent. He was not able to get reactions from the proteoses of egg-albumen. Ten Broeck (1914) found that racemized egg-white had no anaphylactic effect either toward itself or toward native egg-albumen. The simpler the protein disintegration products become the less toxic is their action. The thorough gastric proteolysis undergone by practically all proteins except raw egg-white is a potent factor in preventing allergy. It is well established, however, that even cooked egg-white cannot be used by those sensitized. This does not weaken the case against raw egg, for, as already stated, the coagulated egg-white leaves the stomach little less rapidly than the uncooked. In the texts and manuals on dietetics quoted above the advice to use raw or even cooked eggs is frequently safeguarded by the caution that certain people are peculiarly susceptible to this foodstuff, and it would appear from the cases cited in professional journals that such sensitiveness is not uncommon. Schloss (1913) reported an interesting case in which the feeding of raw egg-white to a child ten days old caused it to react for sears to either cooked or uncooked egg-albumen. The sensitizing substance appeared to be ovomucoid while ovalbumin seemed to be inactive.

With the improved technic for rectal feeding effected by the drip method there has come an increased interest in this kind of alimentation. Since the foods used must be liquid it is natural that raw egg-white should suggest itself for the protein requirements. As early as 1869, Voit and Bauer, however, concluded that this foodstuff was practically worthless for the purposes, a con- 
clusion also reached by Eichorst. Previously it had been stated that salt aided in the absorption of the egg-white, but Eichorst doubted this and stated that the salt caused diarrhea. Czerny and Latschenberger (1874) and Ewald (1S87) also found the salt to be of no value. More recent studies of rectal alimentation tend to show that the amount of protein which can be utilized in this way is unimportant compared to the requirements of the body, a conclusion supported by the work of Adler (1915). Furthermore, it is considered doubtful if unaltered proteins can be absorbed from the colon (Pfeiffer, 1906). If this is so, native egg-white must be considered an especially poor substance for nutrient enemas in view of its pronounced antitryptic properties.

It must not be assumed from the foregoing discussion that native egg-white is considered a toxic or otherwise dangerous substance. But the evidence regarding its behavior in the alimentary canal is taken to show that no advantage accrues to the body by using it raw rather than cooked. Furthermore, when the diet of those seriously ill is considered it may fairly be asked in the light of scientific evidence if the current extensive use of raw eggs is not illogical and inadrisable?

\section{REFERENCES.}

Abderhalden and Pettibone: Ueber den Einfluss des physikalischen Zustandes von Proteinen auf die Raschheit ihres Abbaues durch Fermente, Ztschr. f. physiol. Chem., 1912, lxxxi, 458.

Adler: Value of Rectal Feeding, Am. Jotr. MED. Sc., 1915, cl, 562.

Ascoli: Ueber den Mechanismus der Albuminurie durch Eiereiweiss, München. med. Wchnschr., 1902, xlix, 398.

Ascoli and Vigano: Zur Kenntniss der Resorption der Eiweisskörper, Ztschr. f. physiol. Chem., 1903, xxxix, 283.

Bateman: The Digestibility and Utilization of Egg Proteins, Jour. Biol. Chem., 1916, xxvi, 263.

Bayliss: The Nature of Enzyme Action, London, 1908.

Beaumout: The Physiology of Digestion, Plattsburg, 1833.

Bizarro: On the Influence of Preliminary Heating upon Peptic and Tryptic Proteolysis, Jour. Physiol., 1913, xlvi, 267.

Bruno and Klodnizki: (Quoted from: Babkin, Die äussere Secretion der Verdauungsdrüsen, 1914.)

Cannon: The Passage of Different Foodstuffs from the Stomach and Through the Small Intestine, Am. Jour. Physiol., 1905, xii, 387.

Cathcart and Green: The Rate of Protein Metabolism, Biochem. Jour., 1913, vii, 1. Chambers: A Manual of Diet, Philadelphia, 1875.

Chittenden, Joslin, and Meara: On the Ferments Contained in the Juice of the

Pineapple, Tr. Conn. Acad. Arts. Sc., 1892, viii, 281.

Chittenden: Proteolytic Action of Bromelin, Jour. Physiol., 1894, xv, 249.

Cohnheim: Enzymes, New York, 1912.

Cramer: On the Assimilation of Protein Introduced Parenterally, Jour. Physiol., 190S, xxxvii, 146.

Czerny and Latschenberger: Physiologische Untersuchungen über die Verdauung und

Resorption im Dickdarm des Menschen, Arch. path. Anat. u. Physiol., 1874, lix, 161.

Delezenne and Pozerski: Action empechante de "l'ovalbumine crue" sur la digestion tryptique de "l'ovalbumin coagulee," Comp. Rend. Soc. biol., 1903, lv, 935.

Eichorst: Ueber die Resorption der Albuminate im Dickdarm, Arch. ges. Physiol., 1871 , iv, 570 .

Ely: The Fable of the Egg, New York Med. Jour., 1903, lxxviii, 928. 
Ewald: Ueber die Ernährung mit Pepton- und Eierklystieren, Ztschr. f. klin. Med., 1887, xii, 407.

Falta: Studieren über den Eiweissstoffwechsel, Deutsch. Arch. f. klin. Med., 1906, lxxxvi, 517.

Falta and Noeggerath: Fütterungsversuche mit Künstlicher Nahrung, Beitr. z. chem. Physiol., 1905, vii, 314.

Frank: The Digestibility of White of Egg as Influenced by the Temperature at Which it is Coagulated, Jour. Biol. Chem., 1911, ix, 463.

Frank and Schittenhelm: Ueber die Brauchbarkeit tief abgebauter Eiweissprapärate für die Ernährung, Therap. Monatsh., 1912, xxvi, 112.

Friedenwald and Ruhräh: Diet in Health and Disease, Philadelphia, 1913.

Gompel and Henri: Etude du ralentissement que produit l'albumine d'oeuf crue sur la digestion tryptique de l'albumine coagulee, Comp. Rend. Soc. biol., 1905, lviii, 457 .

Hamburger: Zur Frage der Immunisierung gegen Eiweiss, Wien. klin. Wchnschr., $1902, \mathrm{xv}, 1188$.

Hedin: An Antitryptic Effect of Charcoal, Biochem. Jour., 1906, i, 484.

Hedin: Ueber Verschiedenartige Hemmung der Tryptischen Verdauung, Ztschr. f. physiol. Chem., 1907, lii, 412.

Jonescu: Ueber einc eigenartige Verdauung des Hühner- und Serum-eiweiss durch Papain, Biochem. Ztschr., 1907, ii, 177.

Knapp: Experimenteller Beitrage zur Ernährung von Ratten mit künstlicher Nährung, Ztschr. f, exper. Path. u. Therap., 1908, v, 147.

Langworthy: Eggs and their Uses as Food, United States Department of Agriculture, Farmers' Bull. 128, 1906.

LeClerc and Cook: Metabolism Experiments with Organic and Inorganic Phosphorus, Jour. Biol. Chem., 1906, ii, 203.

London and Sulima: Zum Chemismus der Verdauung im tierischen Körper, Ztschr. f. Physiol. Chem., 1905, xlvi, 209.

Long and Johnson: Activity and Stability of Certain Ferments, Jour. Am. Chem. Soc., 1913, xxxv, 1188.

Maignon: Role des graisses dans l'utilization de l'albumine alimentaire, Comp.

Rend. Soc. biol., 1912, lxxii, 1054.

Maxwell: The Relation of Salivary to Gastric Digestion, Biochem. Jour., 1915, ix, 323 .

Mendel and Lewis: Rate of Elimination of Nitrogen as Influenced by Diet Factors, Jour. Biol. Chem., 1913, xvi, 55.

Mendel and Rockwood: On the Absorption and Utilization of Proteins, Am. Jour. Physiol., 1905, xii, 336.

Mendel and Rose: Experimental Studies on Creatine and Creatinine, Jour.

Biol. Chem., 1911, x, 213.

Oertel: Ueber Ernährung mit Huhnereiern, München., 1883.

Okada: On the Secretion of Bile, Jour. Physiol., 1915, xlix, 45S.

Oppenheimer: Ueber das Schicksal der mit Umgehung des Darmskanals eingefuhrten Eiweissstoffe im Tierkörper, Beitr. z. chem. Physiol., 1904, iv, 263.

Osborne and Campbell: The Protein Constituents of Egg-white, Jour. Am. Chem. Soc., 1900 , xxii, 422 .

Osborne and Mendel: Feeding Experiments with Isolated Food-Substances, Carnegie Institution of Washington, Publication No. 156, 1911.

Pattee: Practical Dietetics with Reference to Diet in Disease, New York, 1910.

Pawlow: The Work of the Digestive Glands, London, 1902.

Pfeiffer: Ueber Ausnutzung von Eiweissklystieren, Ztschr. f. exper. Path., 1906, cxi, 89 .

Röhmann: Ueber die Ernährung von Mäusen mit einer aus einfachen Nahrungsstoffen zusammengesetzen Nahrung, Biochem. Ztschr., 1914, lxiv, 30.

Rubner: Ueber die Ausnutzung einiger Nahrungsmittel in Darmkanals des Menschen, Soc. Biol., 1879, xv, 115.

Sachs: Ueber die Verdauung von rohem Hühnereiweiss durch Papain, Ztschr. f. physiol. Chem., 1907, li, 488 .

Schloss: A Case of Allergy to Common Foods, Am. Jour. Dis. Child., 1912, iii, 34.

Steinitz: Ueber das Verhalten phosphorhaltiger Eiweisskorper im Stoffwechsel, Arch. ges. Physiol., 1898, lxxii, 75.

Stokvis: Hühner-eiweiss und Serum-eiweiss und ihr Verhalten zum thierischen

Organismus, Zentralbl. f. med. Wiss., 1864, ii, 596. 
Talarico: De l'influence de la cuisson sur la digestibilite tryptique de l'albumine d'oeuf, Comp. Rend. Soe. Biol., 1910, lxviii, 662.

Ten Broeck: The Non-antigenic Properties of Racemized Egg Albumin, Jour. Biol. Chem., 1914, xvii, 369.

Thompson: Practical Dietetics, New York, 1902.

Tsuchiya: Ueber das Auftreten des gelösten Eiweisses in den Fäces Erwachsener, Ztschr. f. exper. Path. u. Therap., 1908, v, 455.

Van Alstyne: The Absorption of Proteins without Digestion, Arch. Int. Med., 1913, xii, 372 .

Vernon: Proteids and Trypsin Destruction, Jour. Physiol., 1904, xxxi, 346.

Voit and Bauer: Ueber die Aufsaugung im Dick und Dünndarme, Ztschr. f. Biol., 1869, v, 536.

Vogt: Der Zeitliche Ablauf der Eiweisszersetzung bei Verschiedener Nahrung, Beitr. z. chem. Physiol. u. Path., 1906, viii, 409.

Von Knieriem: Ueber die Verwerthung der Cellulose im Thierischen Organismus, Ztschr. f. Biol., 1885, xxi, 67.

Wells: Chemical Pathology, Philadelphia, 1914.

Winthrop: Diet in Illness and Convalescence, New York, 1899.

Wolf: Die Ausschiedungzeit von Stickstoff, Schwefel, und Kohlenstoff nach Aufnahme von Eiweisssubstanzen und ihren Spaltungsprodukten, Biochem. Ztschr. $1912, x l, 234$. 

3.

H. (x)

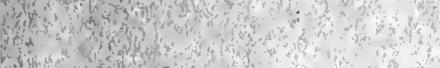

whent

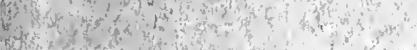

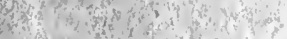

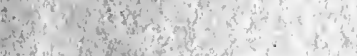

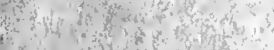

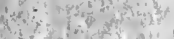

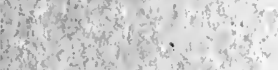

140 to

a d int

(1)

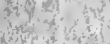

in $x+x^{2}, x^{2}$

(1.

$a+2$ thin 
